\title{
Comparison of Severity of COVID-19 Infection among Patients Using RAAS Inhibitors and Non-RAAS Inhibitors
}

\author{
Paidi Ramakrishna Reddy ${ }^{1} \odot$, Srinivas Samavedam ${ }^{2} \odot$ Narmada Aluru $^{3} \odot$, Rajyalakshmi Boggu ${ }^{4}$
}

\begin{abstract}
Aims and objectives: The aim of the article was to study the safety profile of renin-angiotensin-aldosterone system (RAAS) inhibitor in COVID19-affected Indian patients.

Introduction: Severe acute respiratory syndrome coronavirus 2 (SARS-CoV-2) is responsible for COVID-19 infection. There has been uncertainty about use of RAAS inhibitors in COVID-19. The association of RAAS inhibitors with severity of infection and clinical outcomes was addressed in this study.

Materials and methods: This is a single-center retrospective study from Indian intensive care unit (ICU). A total of 138 were included, who were divided into group A (RAAS inhibitor) and group B (non-RAAS inhibitor). They are followed up till ICU stay during which peak levels of ferritin, D dimer, interleukin- 6 were noted (primary outcome). The number of ventilator days, ICU length of stay, and ICU outcome also compared.

Results: Of 138 patients, 18 are included in group $A$ and 120, in group B. There is no difference in peak levels (mean) D dimer [5,893 vs 7,710, $p 0.46]$, ferritin $[2,388$ vs $3,635, p 0.56]$, interleukin- $6[9,597$ vs $3,625, p 0.06]$. There is no difference in number of ventilator days (2.2 vs 1.78 , $p 0.53$ ) and ICU length of stay (6.5 vs $6.1, p 0.74)$.

Conclusion: RAAS inhibitors can be safely continued in COVID-19 infection. It is not associated with an increase in severity of infection, ICU length of stay, and mortality.

Keywords: ACE inhibitors, Angiotensin receptor blocker, COVID-19, D dimer, Interleukin-6, Renin angiotensin aldosterone system, Serum ferritin, Serum interleukin-6

Indian Journal of Critical Care Medicine (2021): 10.5005/jp-journals-10071-23774
\end{abstract}

\section{INTRODUCTION}

Severe acute respiratory syndrome coronavirus 2 (SARS-CoV-2) was first described in December 2019 in Wuhan, China. It is responsible for coronavirus disease-2019 (COVID-19) infection, a global pandemic affecting millions of population worldwide including healthcare workers with a mortality of $16 \%$ in intensive care unit (ICU) from Western India. ${ }^{2}$ The SARS-CoV-2 is genetically closely related to SARS CoV that emerged in 2002 causing the severe acute respiratory syndrome. It is believed that just like SARS CoV, SARS$\mathrm{CoV}-2$ also uses angiotensin-converting enzyme 2 (ACE2) receptor located on alveolar epithelial cells for entry into the lungs. ${ }^{3}$

The renin-angiotensin-aldosterone system (RAAS) in a closed-loop mechanism maintains sodium concentration and regulates blood pressure. ACE2 receptor, a transmembrane aminopeptidase, has the highest expression in the heart, lungs followed by endothelium, and kidneys. ${ }^{4}$ This receptor counterregulates RAAS through angiotensin II. Following SARS CoV infection, there is downregulation of ACE2 expression that leads to increased activation of RAAS potentiating acute lung injury. ${ }^{5,6}$ In theory, the use of angiotensin-converting enzyme inhibitor (ACEI) and angiotensin receptor blocker (ARB) collectively called RAAS inhibitors should be protective against the virus causing lung injury. But to the contrary, the use of RAAS inhibitors leads to increased expression of ACE receptors in experimental studies, thereby allowing more virus entry into cells causing fatal outcomes. ${ }^{7}$

This uncertainty about the association of RAAS inhibitors and COVID-19 infection led to few observational studies around the world which found that there is no increased risk of infection, mortality with RAAS inhibitors in COVID-19. ${ }^{8-11}$ we aimed to find
${ }^{1-4}$ Department of Critical Care, Virinchi Hospital, Hyderabad, Telangana, India

Corresponding Author: Paidi Ramakrishna Reddy, Department of Critical Care, Virinchi Hospital, Hyderabad, Telangana, India, Phone: +91 9966309982, e-mail: raamrocks24.7@gmail.com

How to cite this article: Reddy PR, Samavedam S, Aluru N, Rajyalakshmi B. Comparison of Severity of COVID-19 Infection among Patients Using RAAS Inhibitors and Non-RAAS Inhibitors. Indian J Crit Care Med 2021;25(4):366-368.

Source of support: Nil

Conflict of interest: None

out the association of RAAS inhibitors in COVID-19 infection among Indian population.

\section{Materials and Methods}

This is a single-center retrospective observational study from a tertiary care center in Hyderabad. The patients admitted to the ICU from May 2020 to July 2020 with COVID-19 infection based on positive reverse transcriptase-polymerase chain reaction (RT-PCR) assay of the nasopharyngeal assay were included in the study. Admission criteria (from emergency unit or wards) to ICU included patients with respiratory rate $>30, \mathrm{SpO}_{2}<90 \%$ on the nonrebreather mask, tachycardia $>120$ /minute, and those with multiorgan failure. A total of 172 were admitted to ICU. Following variables were noted from electronic medical records-duration of symptoms,

(c) Jaypee Brothers Medical Publishers. 2021 Open Access This article is distributed under the terms of the Creative Commons Attribution 4.0 International License (https://creativecommons.org/licenses/by-nc/4.0/), which permits unrestricted use, distribution, and non-commercial reproduction in any medium, provided you give appropriate credit to the original author(s) and the source, provide a link to the Creative Commons license, and indicate if changes were made. The Creative Commons Public Domain Dedication waiver (http://creativecommons.org/publicdomain/zero/1.0/) applies to the data made available in this article, unless otherwise stated. 
$\mathrm{PaO}_{2} / \mathrm{FiO}_{2}(\mathrm{P} / \mathrm{F})$ ratio at the time of admission to hospital, comorbidities, antihypertensive medication, peak levels of ferritin, D dimer, interleukin-6 (IL-6) during hospitalization, number of ventilator days, length of stay in ICU. The patients using ACEls or ARBs were included in group $A$. Group $B$ includes patients on nonRAAS inhibitors, those with no prescription records for hypertension and nonhypertensives.

The primary outcome assessed is the severity of illness based on peak levels of biomarkers-Ferritin, D dimer, interleukin-6, and secondary outcomes are ICU length of stay, mortality.

Patients whose biomarkers are in decreasing trend, off the mechanical ventilator for $>24$ hours, and requiring less than $10 \mathrm{~L} /$ minute of oxygen to maintain $\mathrm{SpO}_{2}>94 \%$ were shifted out.

\section{Statistical Analysis}

Quantitative variables were described as mean ( \pm standard deviation) and qualitative variables as sample and percentage. The $p$ value $<0.05$ is taken as significant. For normal distribution of variables (duration of symptoms), $t$-test is used as a test of significance during comparative analysis, and for rest of variables, Mann-Whitney $U$ test is used for significance due to skewed distribution. Chi-square test is used to compare ICU outcomes. Statistical analysis was performed using SPSS software version 21.

\section{Results}

Of 172 patients admitted to ICU, 138 patients were included in the study due to the nonavailability of biomarkers for few patients. Of these $138,68 \%$ of patients were males and 18 patients categorized to group A. The patients in group A are older than group B (61.9 vs 58.1, $p$ value 0.21 ). The other clinical characteristics are shown in Table 1. The mean duration of symptoms at the time of hospitalization was 5 - 6 days and a majority of patients are hypertensive, diabetic among chronic conditions.

There is no difference in primary outcome between the two groups. The biomarkers D dimer, Ferritin, IL-6 (mean \pm SD) of group A $(5,893 \pm 4,518,2,388 \pm 1,954,9,597 \pm 22,187)$ are comparable to group $B(7,710 \pm 10,396,3,635 \pm 9,015,3,625 \pm 10,898)$, respectively. In this observation, 8 of 18 patients from group $A$ and 52 of 120 from group B had expired with mortality of 55.6 vs $43.3 \%$, respectively ( $p$ value 0.33). Other results are presented in Table 2.

Table 1: Baseline characteristics

\begin{tabular}{lccc}
\hline & $\begin{array}{l}\text { Group A (RAAS } \\
\text { inhibitors) }\end{array}$ & $\begin{array}{c}\text { Group B (non- } \\
\text { RAAS inhibitors) }\end{array}$ & p value \\
\hline Age, mean $( \pm$ SD) & $61.9( \pm 9.9)$ & $58.1( \pm 12.1)$ & 0.21 \\
Sex & $15(83 \%)$ & $80(67 \%)$ & \\
Male & $03(17 \%)$ & $40(33 \%)$ & \\
Female & & & \\
Comorbidities & $18(100 \%)$ & $50(41.6 \%)$ & \\
Hypertension & $11(61 \%)$ & $48(40 \%)$ & \\
Diabetes mellitus & $8(44 \%)$ & $13(10.8 \%)$ & \\
Coronary artery disease & $1(5.5 \%)$ & $16(13 \%)$ & \\
Hypothyroid & $1(5.5 \%)$ & $5(4 \%)$ & \\
Airway disease & $36(30 \%)$ & & \\
Nil & $6.22( \pm 2.4)$ & $5.6( \pm 2.4)$ & 0.40 \\
Duration of symptoms, & & & \\
mean $( \pm$ SD $)$ & $203.5( \pm 122.5)$ & $204.5( \pm 118.5)$ & 0.97 \\
P/F ratio $( \pm$ SD $)$ & & & \\
\hline
\end{tabular}

Table 2: Primary and secondary outcomes

\begin{tabular}{lccc}
\hline Outcome & $\begin{array}{l}\text { Group A } \\
\text { (RAAS inhibitors) }\end{array}$ & $\begin{array}{l}\text { Group B (non- } \\
\text { RAAS inhibitors) }\end{array}$ & p value \\
\hline $\begin{array}{l}\text { Peak levels } \\
\text { D dimer, mean } \\
( \pm \text { SD) }\end{array}$ & $5893.3( \pm 4518.7)$ & $7710.5( \pm 10395.9)$ & 0.46 \\
$\begin{array}{l}\text { Ferritin, mean } \\
( \pm \text { SD) }\end{array}$ & $2388.1( \pm 1954.2)$ & $3635.3( \pm 9015.1)$ & 0.56 \\
$\begin{array}{l}\text { Interleukin-6 } \\
\text { mean }( \pm S D)\end{array}$ & $9597.3( \pm 22186.9)$ & $3625.1( \pm 10897.9)$ & 0.06 \\
$\begin{array}{l}\text { Ventilator days } \\
\text { ICU length of stay }\end{array}$ & $2.22( \pm 3.1)$ & $1.78( \pm 2.7)$ & 0.53 \\
$\begin{array}{l}\text { ICU outcome } \\
\text { (mortality) }\end{array}$ & $55.6 \%$ & $6.1( \pm 4.0)$ & 0.74 \\
\hline
\end{tabular}

\section{Discussion}

In this single-center retrospective study, the use of RAAS inhibitors had not led to increased severity of COVID-19 infection. There is no difference in ICU length of stay, ventilator days (invasive) when compared. The study by Zhang et al. showed that the use of RAAS inhibitors is associated with low mortality, but they have compared results among hypertensive patients only, unlike our study where our control group is cohort of hypertensive and nonhypertensives. ${ }^{8}$ The position statements by the European Society of Cardiology and the American Heart Association regarding RAAS inhibitors support our findings. Recent observational studies also proved the safe use of RAAS inhibitors, they do not increase the risk of COVID-19 infection or severity of illness. ${ }^{9,10}$

\section{Conclusion}

RAAS inhibitors can be used safely, and there is no increased risk of severity of illness, mortality, and ICU length of stay due to COVID19 infection.

\section{Limitations}

A study from single-center retrospective study.

\section{AbBreviations}

$\begin{array}{ll}\text { ACE2 } & - \text { Angiotensin-converting enzyme } 2 \\ \text { ACEI } & - \text { Angiotensin-converting enzyme inhibitor } \\ \text { ARB } & - \text { Angiotensin receptor blocker } \\ \text { COVID-19 } & - \text { Coronavirus disease } 2019 \\ \text { ICU } & - \text { Intensive care unit } \\ \text { IL-6 } & - \text { Interleukin-6 } \\ \text { RAAS } & - \text { Renin-angiotensin-aldosterone system } \\ \text { SARS-CoV-2 } & - \text { Severe acute respiratory syndrome corona virus-2 } \\ \text { SD } & - \text { Standard deviation }\end{array}$

\section{ORCID}

P Ramakrishna Reddy (1) https://orcid.org/0000-0002-4219-0020 Srinivas Samavedam (1) https://orcid.org/0000-0001-6737-8663 Narmada Aluru (1) https://orcid.org/0000-0002-4848-3430 Rajyalakshmi B ㄴ https://orcid.org/0000-0001-9120-417X

\section{References}

1. Wu Z, McGoogan JM. Characteristics of and important lessons from the coronavirus disease 2019 (COVID-19) outbreak in China: summary of a report of 72314 cases from the Chinese Center for Disease 
Control and Prevention. JAMA 2020;323(13):1239-1242. DOI: 10.1001/ jama.2020.2648

2. Shukla U, Chavali S, Mukta P, Mapari A, Vyas A. Initial experience of critically ill patients with COVID-19 in Western India: a case series. Indian J Crit Care Med 2020;24(7):509-513. DOI: 10.5005/ jp-journals-10071-23477.

3. Liu J, Zheng X, Tong Q, Li W, Wang B, Sutter K, et al. Overlapping and discrete aspects of the pathology and pathogenesis of the emerging human pathogenic coronaviruses SARS-CoV, MERS-CoV, and 2019nCoV. J Med Virol 2020;92(5):491-494. DOI: 10.1002/jmv.25709.

4. Velavan TP, Meyer CG. The COVID-19 epidemic. Trop Med Int Health 2020;25(3):278-280. DOI: 10.1111/tmi.13383.

5. Kuba K, Imai Y, Rao S, Gao H, Guo F, Guan B, et al. A crucial role of angiotensin converting enzyme 2 (ACE2) in SARS coronavirusinduced lung injury. Nat Med 2005;11(8):875-879. DOI: 0.1038/nm1267.

6. Kuba K, Imai Y, Ohto-Nakanishi T, Penninger JM. Trilogy of ACE2: a peptidase in the renin-angiotensin system, a SARS receptor, and a partner for amino acid transporters. Pharmacol Ther 2010;128(1):119128. DOI: 10.1016/j.pharmthera.2010.06.003.

7. Ferrario CM, Jessup J, Chappell MC, Averill DB, Brosnihan KB, Tallant $E A$, et al. Effect of angiotensin-converting enzyme inhibition and angiotensin II receptor blockers on cardiac angiotensin-converting enzyme 2. Circulation 2005;111(20):2605-2610.

8. Zhang P, Zhu L, Cai J, Lei F, Qin JJ, Xie J, et al. Association of inpatient use of angiotensin-converting enzyme inhibitors and angiotensin II receptor blockers with mortality among patients with hypertension hospitalized with COVID-19. Circ Res 2020;126(12):1671-1681. DOI: 10.1161/CIRCRESAHA.120.317134

9. Hippisley-Cox J, Young D, Coupland C, Channon KM, Tan PS, Harrison DA, et al. Risk of severe COVID-19 disease with ACE inhibitors and angiotensin receptor blockers: cohort study including 8.3 million people. Heart 2020;106(19):1503-1511. DOI: 10.1136/ heartjnl-2020-317393.

10. Liu X, Long C, Xiong Q, Chen C, Ma J, Su Y, et al. Association of angiotensin converting enzyme inhibitors and angiotensin II receptor blockers with risk of COVID-19, inflammation level, severity, and death in patients with COVID-19: a rapid systematic review and meta-analysis. Clin Cardiol 2020:10.1002/clc.23421. DOI: 10.1002/ clc.23421.

11. Rico-Mesa JS, White A, Anderson AS. Outcomes in patients with COVID-19 infection taking ACEI/ARB. Curr Cardiol Rep 2020;22(5):31. DOI: $10.1007 / \mathrm{s} 11886-020-01291-4$ 